\title{
Correction to: Europium and terbium Schiff base peptide complexes as potential antimicrobial agents against Salmonella typhimurium and Pseudomonas aeruginosa
}

\author{
Jindrich Kynicky ${ }^{1,2}$ - Vedran Milosavljevic ${ }^{2,3} \cdot$ Pavlina Jelinkova $^{2,3} \cdot$ Yazan Haddad $^{2,3}$. \\ Miguel Angel Merlos Rodrigo ${ }^{2,3} \cdot$ Hana Buchtelova ${ }^{2,3} \cdot$ Zuzana Bytesnikova $^{2,3} \cdot$ Martin Brtnicky $^{1,2} \cdot$ Lukas Richtera $^{2,3}$. \\ Pavel Kopel $^{2,3} \cdot$ Vojtech Adam ${ }^{2,3}$ (D)
}

Published online: 30 December 2021

(c) Institute of Chemistry, Slovak Academy of Sciences 2021

\section{Correction to: Chemical Papers (2018) 72:1437-1449 https://doi.org/10.1007/s11696-018-0400-3}

Recently, the authors became aware of an error in Figure 7A of the indicated paper, where inadvertently the same microscope image was used twice to represent the control. We now present a fully corrected version of the entire figure 7 . In making this correction, the authors note that there is no impact on the conclusions of the published paper. The authors would like to express their sincerest apologies to the editorial board and readership for this error.

Corrected Fig. 7

The original article can be found online at https://doi.org/10.1007/ s11696-018-0400-3.

Vojtech Adam

vojtech.adam@mendelu.cz

1 Department of Geology and Pedology, Mendel University in Brno, Zemedelska 1, 61300 Brno, Czech Republic

2 Central European Institute of Technology, Brno University of Technology, Purkynova 123, 61200 Brno, Czech Republic

3 Department of Chemistry and Biochemistry, Mendel University in Brno, Zemedelska 1, 61300 Brno,

Czech Republic 

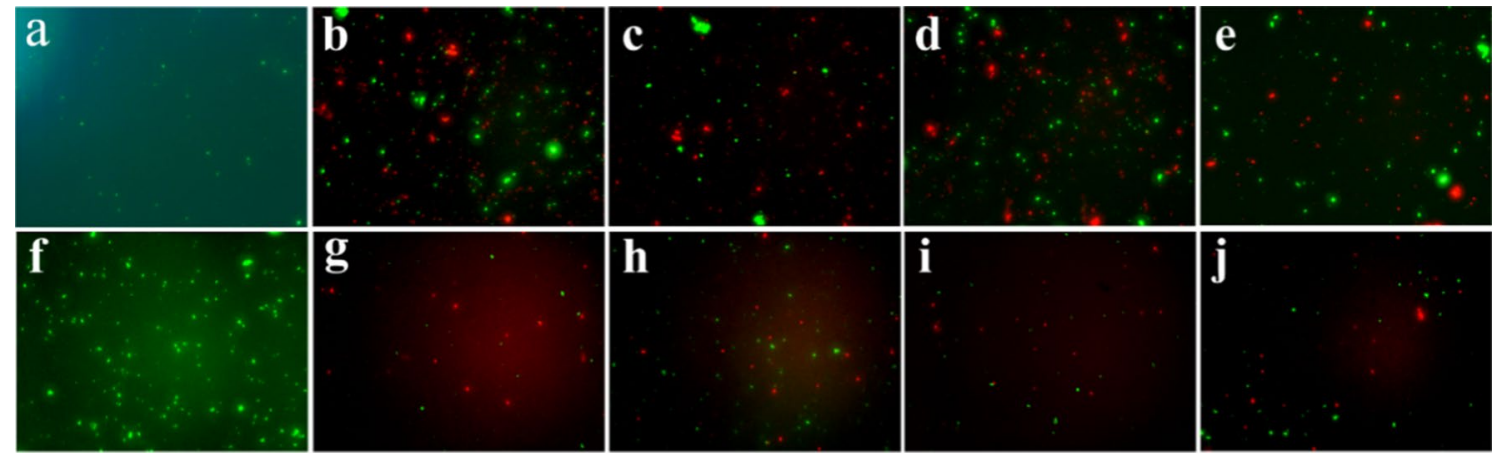

Fig. 7 Microscopic assay for evaluation of live/dead bacterial cells. a Fluorescence images of the same samples at $528 \mathrm{~nm}$ (green) for SYTO9 signal of $P$. aeruginosa, live/dead proportions of $P$. aeruginosa cells stained with PI after application of $\mathbf{b}$ Eu-S-5-peptide, $\mathbf{c}$ Eu-S-6-peptide, d Tb-S-5-peptide, e Tb-S-5-peptide. f Fluores- cence images of the same samples at $528 \mathrm{~nm}$ (green) for SYTO9 signal of S. typhimurium, live/dead proportions of S. typhimurium cells stained with PI after application of $\mathbf{g}$ Eu-S-5-peptide, $\mathbf{h}$ Eu-S-6-peptide, $\mathbf{i}$ Tb-S-5-peptide, $\mathbf{j}$ Tb-S-5-peptide

Publisher's Note Springer Nature remains neutral with regard to jurisdictional claims in published maps and institutional affiliations. 